\title{
Influence of extractants and filter materials in the extraction of dissolved organic matter (DOM) from subtropical agricultural soil
}

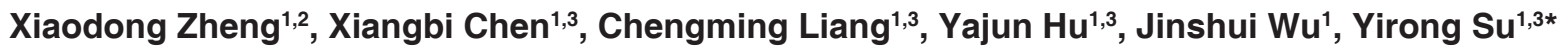 \\ ${ }^{1}$ Key Laboratory of Agro-ecological Processes in Subtropical Region, Institute of Subtropical Agriculture, The Chinese Academy of Sciences, \\ Changsha 410125, China, ${ }^{2}$ University of Chinese Academy of Sciences, Beijing 100039, PR China, ${ }^{3}$ Huanjiang Observation and Research \\ Station for Karst Ecosystem, Huanjiang 547100, China
}

\section{A B S T R A C T}

\begin{abstract}
The dissolved organic matter (DOM) plays an important role in ecological processes in agricultural ecosystems. However, composition of DOM extracted by different methods remains unclear. In this study, pyrolysis-gas-chromatography/mass spectrometry (Py-GCMS) was used to investigate the content and chemical composition of DOM extracted by aqueous $\mathrm{K}_{2} \mathrm{SO}_{4}$ or $\mathrm{H}_{2} \mathrm{O}$ and filter paper (FP) or membrane (FM). The results showed that dissolved organic carbon (DOC) content extracted by $\mathrm{K}_{2} \mathrm{SO}_{4}$ was $0.83-11.2$ times higher than that extracted by $\mathrm{H}_{2} \mathrm{O}$, while it increased by $10.1-75.0 \%$ when filtered by FP compared to that filtered by FM. Compared with the $\mathrm{H}_{2} \mathrm{O}$ extract, the $\mathrm{K}_{2} \mathrm{SO}_{4}$ one contained lower proportions of aromatic compounds. The relative proportions of hydrophobic compounds in the $\mathrm{K}_{2} \mathrm{SO}_{4}$ extract (9.7-89.7\%), were higher than in $\mathrm{H}_{2} \mathrm{O}$ one (2.6-63.5\%), whereas the proportions of hydrophilic compounds exhibited the opposite trend $(p<0.05)$. The content and complexity of the DOM extracted by the $\mathrm{FP}-\mathrm{K}_{2} \mathrm{SO}_{4}$ method was higher than that obtained by $\mathrm{FM}-\mathrm{H}_{2} \mathrm{O}$ one. Taken together, the $\mathrm{K}_{2} \mathrm{SO}_{4}$ and $\mathrm{H}_{2} \mathrm{O}$ extractants affected both the quantity and quality of DOM, whereas the FP and FM filter materials only influenced the DOC content $(p<0.05)$. Consequently, effect of the extraction method on DOM properties should be considered when studying DOM composition and corresponding ecological processes.
\end{abstract}

Keywords: Chemical compound; Dissolved organic matter; Extractant; Filter material

\section{INTRODUCTION}

Dissolved organic matter (DOM) is a readily available source of carbon $(\mathrm{C})$, immediate energy, and nutrients for soil microbes (Chantigny et al., 2014). Although DOM only accounts for less than $1 \%$ of the total soil organic matter (SOM), its high turnover rate indicates that it plays a key role in physicochemical and biological processes in soil (Boddy et al., 2007). The quantity of DOM reflects the magnitude of the available nutrient pool in soil, as inorganic nutrients $(\mathrm{N}, \mathrm{P}$, etc.) are released into soil during the microbial degradation of DOM (McDowell et al., 2003). The chemical composition of DOM greatly influences its ecological processes, such as degradation, adsorption, and migration (Chen and Sparks, 2015; Troyer et al., 2011). For example, low-molecular-weight organic compounds, such as carbohydrates, amino acids, and proteins, are highly degradable and are accompanied by gas emissions and the release of inorganic nutrients (Van Hees et al., 2005). Complex DOM components, such as aromatic and humic-like compounds, are recalcitrant to microbial degradation (Straathof et al., 2014). Hydrophilic DOM compounds, which are less adsorptive and highly mobile, are readily lost from soil, whereas hydrophobic compounds are preferentially adsorbed by soil particles (Jardine et al., 1989). Therefore, DOM composition plays an important role in ecological processes.

The characteristics of DOM are dependent on its extraction method, including extraction time, temperature, water/soil ratio, extractant, and filter material, as examples (Jones and Willett, 2006; Rousk and Jones, 2010). Among these factors, the extractant and filter material are most likely to affect DOM characteristics, such as content and chemical composition (Peltzer et al., 1996; Jones and Willett, 2006). Presently, the classic procedure for DOM extraction is

\footnotetext{
${ }^{*}$ Corresponding author:

Yirong Su, Institute of Subtropical Agriculture, The Chinese Academy of Sciences, Changsha 410125, China.
}

Tel: +86 73184615222/Fax: +86 73184612685. E-mail: yrsu@isa.ac.cn. 
based on the use of deionized water and filtration through a 0.45- $\mu \mathrm{m}$ membrane (FM- $\mathrm{H}_{2} \mathrm{O}$ method) (Ogura, 1974; Jardine et al., 1989; Feng et al., 2014). Operationally, salt solutions $\left(\mathrm{K}_{2} \mathrm{SO}_{4}\right.$ or $\left.\mathrm{KCl}\right)$ and Whatman No. 42 filter paper $(2.5 \mu \mathrm{m})$ have also been used (FP- $\mathrm{K}_{2} \mathrm{SO}_{4}$ or $\mathrm{FP}-\mathrm{KCl}$ ) (Jones and Willett, 2006; McDowell et al., 2006). Unfortunately, DOM extracted by different methods may lead to different results. For example, the FM- $\mathrm{H}_{2} \mathrm{O}$-extracted DOC content was higher in paddy soil than in upland soil, whereas the opposite trend was observed in similar soils when the FP$\mathrm{K}_{2} \mathrm{SO}_{4}$ method was used (Han et al., 2007; Li et al., 2008). $\mathrm{Lu}$ et al. (2004) found that the dynamics of the waterextractable organic-C content was significantly affected by the incorporation and decomposition of photosynthesized rice $\mathrm{C}$ in paddy soil, but the salt-extractable organic $\mathrm{C}$ content was less affected during rice-plant growth, indicating that extractants can affect the DOC content. To date, considerable attention has been paid to quantifying DOC content and its extraction efficiency. However, the chemical composition of DOM extracted using different methods is largely unknown.

Generally, salt solutions afford higher extraction efficiencies compared with $\mathrm{H}_{2} \mathrm{O}$ (Rousk and Jones, 2010). On the other hand, solutions filtered by filter material with pore sizes exceeding $0.45 \mu \mathrm{m}$ could contain very fine particulate organic carbon (Nebbioso and Piccolo, 2013). Here, we hypothesize that the composition of the DOM extracted with a salt solution and FP (pore size $>0.45 \mu \mathrm{m}$ ) is more complex than that extracted with $\mathrm{H}_{2} \mathrm{O}$ and a filter membrane (pore size: $0.45 \mu \mathrm{m}$ ). Consequently, the present study is aimed at identifying the effects of the extractant and filter material on the chemical composition of DOM from agricultural soils.

\section{MATERIALS AND METHODS}

\section{Soil}

To investigate the common characteristics of soil DOM by different extraction methods, six agricultural soils $(0-15 \mathrm{~cm}$ depth) were collected in March 2014 in subtropical China. Soils were stored at the field moisture content in airtight polypropylene bags and immediately transported to the laboratory. The samples were divided into two parts. One was stored at $4{ }^{\circ} \mathrm{C}$ prior to $\mathrm{DOC}$ extraction, the other was used for $\mathrm{SOC}$ and soil $\mathrm{pH}$ analysis after drying under low-light conditions. The main soil properties and climate factors are shown in Table 1.

\section{DOC extraction methods}

Field-moist soil was mixed with either distilled $\mathrm{H}_{2} \mathrm{O}$ or $0.5 \mathrm{M} \mathrm{K}_{2} \mathrm{SO}_{4}$ (w/v: 1:2) in a polypropylene bottle and placed on an orbital shaker at $200 \mathrm{rpm}$ for $1 \mathrm{~h}$. The samples were then centrifuged at 12,000 × $\mathrm{g}$ (Hitachi, Himac CR 22GII/Rotor, R20A2) for $10 \mathrm{~min}$ at $4{ }^{\circ} \mathrm{C}$ to remove suspended solids. The supernatant was filtered either through a $0.45-\mu \mathrm{m}$ filter membrane with pumping or Whatman No. 42 filter paper (the smallest pore size in commonly used filter papers: $2.5 \mu \mathrm{m}$ ), and a small aliquot of each filtrate was retained for DOC-concentration and $\mathrm{E}_{254}$ analysis. The remaining filtrate was freeze-dried at $-55{ }^{\circ} \mathrm{C}$ for pyrolysis-gaschromatography/mass spectrometry (Py-GC/MS) analysis.

\section{Analytical methods}

The concentration of DOC in each extract was determined using an automated TOC analyser (Teledyne Tekmar Phoenix 8000, Mason, USA). The organic carbon in the soil was measured using the $\mathrm{K}_{2} \mathrm{CrO}_{7}-\mathrm{H}_{2} \mathrm{SO}_{4}$ oxidation procedure, and the $\mathrm{pH}$ was determined with distilled water in a soil: water ratio of 1:2.5 (w/v) using a $\mathrm{pH}$ meter. The UV absorbance at $254 \mathrm{~nm}\left(\mathrm{E}_{254}\right.$, Shimadzu UV-2450, Shimadzu Corporation, Kyoto, Japan) was used to estimate its aromaticity (Kalbitz et al., 2003). Prior to any UV measurement, the C concentration of DOM was adjusted into $2 \mathrm{mg} \mathrm{L}^{-1}$.

The freeze-dried filtrates $(0.5 \mathrm{mg})$ were introduced as solids via an injector into the SGE pyrojector and pyrolyzed at $450{ }^{\circ} \mathrm{C}$. The temperature of the column was held at $5^{\circ} \mathrm{C}$ for $2 \mathrm{~min}$, then raised at a rate of $5^{\circ} \mathrm{C} / \mathrm{min}$ to $290{ }^{\circ} \mathrm{C}$ and kept at this temperature for $15 \mathrm{~min}$. Helium was used as the carrier gas at a flow rate of $1 \mathrm{~mL} / \mathrm{min}$. The injection mode had a split ratio of approximately 1:5. GC/MS of the pyrolysates was performed on a Hewlett Packard 5890 gas chromatograph equipped with an HP 5970 mass-selective detector (Perkin-Elmer, Shelton, CT, USA). Chromatography was carried out on a fused silica column (30 m $\times 0.25 \mathrm{~mm}$ i.d., $0.25 \mu \mathrm{m}$ film thickness) coated with DB5MS (modified 5\% phenyl, 95\% methyl silicone). Mass spectra (1 scan/s) were recorded under electron impact at $70 \mathrm{eV}$. Compound identification was conducted based on comparisons of mass spectra with the NIST-library (National Institute of Standards and Technology Mass Spectral Library) database, published spectra, and authentic standards (Saiz-Jimenez, 1994; Sihombing et al., 1996; Zhou et al., 2010)., We correlated the pyrolysis products with compound types in the original DOM solutions according to the pyrogram. Products not detected in samples were given a zero value in the statistical treatments. The identified products were categorized into several general chemical classes, such as lipids, aromatics, organic acids, phenols and N-compounds (Lu et al., 2005; Plant et al., 2015). The lipids and aromatics were classified as hydrophobic compounds (Ho-compounds) (Karickhoff et al., 1979; Kalmykova et al., 2014), whereas the organic acids, phenols, and $\mathrm{N}$-compounds were grouped as hydrophilic compounds (Hi-compounds) (Kalbitz et al., 2003; Pullicino and Gigliotti, 2007). 
Table 1: Description of locations and basic properties

\begin{tabular}{|c|c|c|c|c|c|c|}
\hline Soil number & 1 & 2 & 3 & 4 & 5 & 6 \\
\hline Location & 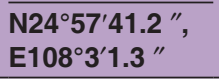 & $\begin{array}{l}\mathrm{N}^{2} 9^{\circ} 30^{\prime} 8.9^{\prime \prime}, \\
\mathrm{E}^{\prime 1} 2^{\circ} 46^{\prime} 27.2^{\prime \prime}\end{array}$ & $\begin{array}{l}\mathrm{N}_{2}^{\circ} 9^{\circ} 5^{\prime} 49.7^{\prime \prime}, \\
\mathrm{E} 111^{\circ} 31^{\prime} 57.5^{\prime \prime}\end{array}$ & $\begin{array}{l}\text { N24둑'38.4 ", } \\
\text { E108 } 0^{\circ} 52.0^{\prime \prime}\end{array}$ & $\begin{array}{l}\mathrm{N}^{\circ} 29^{\circ} 0.5^{\prime \prime}, \\
\mathrm{E}^{\prime} 2^{\circ} 45^{\prime} 58.5^{\prime \prime}\end{array}$ & $\begin{array}{l}\mathrm{N}^{2} 9^{\circ} 14^{\prime} 58.3^{\prime \prime}, \\
\mathrm{E} 111^{\circ} 32^{\prime} 22.8^{\prime \prime}\end{array}$ \\
\hline Soil type & Limestone & Red soil & Red soil & Limestone & Red soil & Red soil \\
\hline Soil parent & Dolomite & Quaternary red clay & Quaternary red clay & Dolomite & Quaternary red clay & Quaternary red clay \\
\hline $\begin{array}{l}\text { Water } \\
\text { management }\end{array}$ & Precipitation & Precipitation+irrigation & Precipitation+irrigation & Precipitation & precipitation+irrigation & precipitation+irrigation \\
\hline Fertilizer & $\begin{array}{l}\text { Chemical } \\
\text { fertilizer+manure }\end{array}$ & $\begin{array}{l}\text { Chemical } \\
\text { fertilizer+straw }\end{array}$ & $\begin{array}{l}\text { Chemical } \\
\text { fertilizer+straw }\end{array}$ & $\begin{array}{l}\text { Chemical } \\
\text { fertilizer+manure }\end{array}$ & $\begin{array}{l}\text { Chemical } \\
\text { fertilizer+straw }\end{array}$ & $\begin{array}{l}\text { Chemical } \\
\text { fertilizer+straw }\end{array}$ \\
\hline Plantation & $\begin{array}{l}\text { Maize+sweet } \\
\text { potato }\end{array}$ & Cotton+wheat & Cotton+oilseed rape & rice & rice & rice \\
\hline $\begin{array}{l}\text { Annual } \\
\text { mean } \\
\text { temperature }\end{array}$ & 19.9 & 16.9 & 16.5 & 19.9 & 16.9 & 16.5 \\
\hline Altitude $(\mathrm{m})$ & 516 & 51 & 99 & 489 & 32 & 88 \\
\hline $\mathrm{pH}$ & 7.26 & 8.00 & 4.93 & 7.66 & 7.58 & 4.87 \\
\hline $\mathrm{SOC}(\mathrm{g} / \mathrm{kg})$ & 12.8 & 14.8 & 11.5 & 32.8 & 19.9 & 21.7 \\
\hline $\mathrm{DOC}(\mathrm{mg} / \mathrm{kg})$ & 10.8 & 16.7 & 15.7 & 26.6 & 16.4 & 47.8 \\
\hline $\begin{array}{l}\text { DOCl } \\
\text { SOC (\%) }\end{array}$ & 0.08 & 0.11 & 0.13 & 0.08 & 0.08 & 0.22 \\
\hline$E_{254}$ & 0.28 & 0.15 & 0.14 & 0.05 & 0.28 & 0.15 \\
\hline
\end{tabular}

Abbreviations: m, meters; SOC (g/kg), soil organic carbon; DOC (mg/kg soil), dissolved organic carbon; $\mathrm{E}_{254}, \mathrm{UV}_{\mathrm{absorbance}}$ of $2 \mathrm{mg} / \mathrm{L} \mathrm{DOC} \mathrm{at} 254 \mathrm{~nm}$. The equation used to calculate SOC was: $\mathrm{C} \times 5 / \mathrm{V}_{0} \times\left(\mathrm{V}_{0}-\mathrm{V}\right) \times 10^{-3} \times 3 \times 1.1 \times 10^{3} / \mathrm{m} \times \mathrm{k}$, where $\mathrm{C}$ is the concentration of potassium dichromate $(0.8000 \mathrm{~mol} / \mathrm{L})$, ' 5 ' ( $\left.\mathrm{mL}\right)$ is the volume of the potassium dichromate solution, $\mathrm{V}_{0}$ is the volume of the ferrous sulfate solution ( $\mathrm{mL}$ ) used to titrate the blank control, $\mathrm{V}$ is the volume of the ferrous sulfate solution $(\mathrm{mL})$ used to titrate the sample, ' $10^{-3}$ ' converts $\mathrm{mL}$ to $\mathrm{L}$, ' 3 ' is a quarter of the molar mass of the carbon atom, ' 1.1 ' is the oxidation correction coefficient, $\mathrm{m}$ is the mass of fresh soil $(\mathrm{g})$, and $\mathrm{k}$ is the water coefficient. The equation used to calculate $\mathrm{DOC}$ was: $\mathrm{C} \times \mathrm{V} \times 10^{-3} /\left(\mathrm{m} \times 10^{-3}\right) \times \mathrm{k}$, where $\mathrm{C}$ is the concentration of DOC determined by the automated TOC analyser (mg/L), $\mathrm{V}$ is the volume of extracted $\mathrm{DOC}$ solution ( $\mathrm{mL}$ ), ' $10^{-3}$ ' converts $\mathrm{mL}$ to $\mathrm{L}$ and $\mathrm{g}$ to $\mathrm{kg}, \mathrm{m}$ is the mass of fresh soil $(\mathrm{g})$, and $\mathrm{k}$ is the water coefficient. The $\mathrm{E}_{254}$ value was obtained at $254 \mathrm{~nm}$ with an ultraviolet spectrophotometer after the concentration (C) of DOM was adjusted into $2 \mathrm{mg} / \mathrm{L}$.

\section{Statistics}

The significance of the differences among the four extraction methods was analysed using $t$-tests of paired samples at a significance level of $p<0.05$ in the SPSS Statistics 16.0 statistical software package (IBM, USA). The figures were created using Origin 8.0.

\section{RESULTS}

\section{DOC content and aromaticity}

The DOC contents of the treated samples were in the order: $\mathrm{FP}-\mathrm{K}_{2} \mathrm{SO}_{4}>\mathrm{FM}-\mathrm{K}_{2} \mathrm{SO}_{4}>\mathrm{FP}_{-} \mathrm{H}_{2} \mathrm{O}>\mathrm{FM}-\mathrm{H}_{2} \mathrm{O}(p<0.05)$. Among extractions that used the same filter material (FM or FP), the DOC contents extracted by $\mathrm{K}_{2} \mathrm{SO}_{4}$ were 1.17-11.2 and 0.83-6.83 times higher than those extracted by $\mathrm{H}_{2} \mathrm{O}$, respectively. Among extractions that used the same extractant $\left(\mathrm{H}_{2} \mathrm{O}\right.$ or $\left.\mathrm{K}_{2} \mathrm{SO}_{4}\right)$, the DOC contents of the FP filtrates increased by $12.7-75 \%$ and $10.1-61.5 \%$ compared with those of the FM filtrates, respectively (Table 2). This indicates that the DOC content is mostly influenced by the extractant, and to a lesser extent by the filter material.

$\mathrm{E}_{254}$ values correlate positively with the proportion of aromatic compounds in a sample. For the same filtration material, the $\mathrm{E}_{254}$ values for the $\mathrm{K}_{2} \mathrm{SO}_{4}$ extracts are significantly lower than those of the $\mathrm{H}_{2} \mathrm{O}$ extracts (Table 2), indicating that the $\mathrm{K}_{2} \mathrm{SO}_{4}$ extracts contain a lower proportion of aromatic compounds. For the same extractant, there was no significant difference in the $\mathrm{E}_{254}$ value between the FM and FP filtrates.

\section{Hydrophilic and hydrophobic components in DOC extractions}

Hi-compounds account for 36.5-97.4\% and 10.3-90.3\% of the $\mathrm{H}_{2} \mathrm{O}$ and $\mathrm{K}_{2} \mathrm{SO}_{4}$ extracts, whereas Ho-compounds account for 2.6-63.5\% and 9.7-89.7\%, respectively. The Hi- and Ho-compounds extracted by the different methods consist mainly of organic acids and lipids, respectively, with both of these components accounting for $75 \%$ to $100 \%$ of the total DOM (Table 3).

For the FP filtrates, the relative proportion of Hocompounds is higher and that of the Hi-compounds is lower in the $\mathrm{K}_{2} \mathrm{SO}_{4}$ extracts compared to the $\mathrm{H}_{2} \mathrm{O}$ extracts $(p<0.05)$. However, for the FM filtrates, there are no significant changes in the relative proportions of these components between the $\mathrm{K}_{2} \mathrm{SO}_{4}$ and $\mathrm{H}_{2} \mathrm{O}$ extracts. These results indicate that the DOM composition, in response to the extraction method, is also affected by the filter material type, although the difference in the DOM composition between the FM and FP filtrates is not significant using the same extractant. The proportion of Ho-compounds in the DOM extracted by the FP- $\mathrm{K}_{2} \mathrm{SO}_{4}$ method is significantly higher than that in $\mathrm{FM}-\mathrm{H}_{2} \mathrm{O}$, whereas the Hi-compounds exhibit the opposite trend $(p<0.05)$. 
Table 2: DOC content and UV absorbance

\begin{tabular}{|c|c|c|c|c|c|c|c|c|c|c|c|c|}
\hline \multirow[t]{2}{*}{ Soil number } & \multicolumn{6}{|c|}{ DOC content $(\mathrm{mg} / \mathrm{kg})$} & \multicolumn{6}{|c|}{$E_{254}$} \\
\hline & \multicolumn{6}{|c|}{123456} & \multicolumn{6}{|c|}{123456} \\
\hline $\mathrm{FM}-\mathrm{H}_{2} \mathrm{O}$ & 13.2 & 17.9 & 9.9 & 48.7 & 20.6 & $20.6 d$ & 0.33 & 0.13 & 0.15 & 0.05 & 0.08 & $0.19 a$ \\
\hline $\mathrm{FM}-\mathrm{K}_{2} \mathrm{SO}_{4}$ & 28.6 & 67.4 & 120.3 & 172.3 & 63.0 & $87.1 \mathrm{~b}$ & 0.04 & 0.07 & 0.03 & 0.02 & 0.04 & $0.03 b$ \\
\hline $\mathrm{FP}-\mathrm{H}_{2} \mathrm{O}$ & 23.12 & 24.4 & 16.9 & 54.9 & 27.4 & $27.3 c$ & 0.29 & 0.21 & 0.19 & 0.06 & 0.11 & $0.27 a$ \\
\hline $\mathrm{FP}-\mathrm{K}_{2} \mathrm{SO}_{4}$ & 42.2 & 92.5 & 132.4 & 219.2 & 74.9 & $140.7 a$ & 0.03 & 0.07 & 0.03 & 0.03 & 0.06 & $0.03 b$ \\
\hline
\end{tabular}

The different superscript letters indicate significant differences at the $\mathrm{P}<0.05$ level among four extraction methods. Abbreviations: $\mathrm{FM}-\mathrm{H}_{2} \mathrm{O} ; \mathrm{Filter}$ membrane- $\mathrm{H}_{2} \mathrm{O}$. FM- $\mathrm{K}_{2} \mathrm{SO}_{4}$; Filter membrane- $\mathrm{K}_{2} \mathrm{SO}_{4}$. $\mathrm{FP}-\mathrm{H}_{2} \mathrm{O}$; Filter paper- $\mathrm{H}_{2} \mathrm{O}$. FP- $\mathrm{K}_{2} \mathrm{SO}_{4}$; Filter paper- $\mathrm{K}_{2} \mathrm{SO}_{4}$

Table 3: Relative proportion of DOC compounds obtained by different extraction and filtration methods (\%)

\begin{tabular}{|c|c|c|c|c|c|c|c|c|}
\hline \multicolumn{2}{|c|}{ Compound type } & \multirow{2}{*}{$\begin{array}{c}\text { Ho-compounds } \\
51.9\end{array}$} & \multirow{2}{*}{$\begin{array}{c}\text { Lipids } \\
47.8\end{array}$} & \multirow{2}{*}{$\frac{\text { Aromatics }}{4.1}$} & \multirow{2}{*}{$\frac{\text { Hi-compounds }}{48.1}$} & \multirow{2}{*}{$\frac{\text { Organic acids }}{48.1}$} & \multirow{2}{*}{$\frac{\text { Phenols }}{0}$} & \multirow{2}{*}{$\frac{N \text {-compounds }}{0}$} \\
\hline $\mathrm{FM}-\mathrm{H}_{2} \mathrm{O}$ & 1 & & & & & & & \\
\hline & 2 & 2.6 & 2.6 & 0 & 97.4 & 97.4 & 0 & 0 \\
\hline & 3 & 34.3 & 30.7 & 3.6 & 65.7 & 62.3 & 2.1 & 1.3 \\
\hline & 4 & 15.7 & 11.6 & 4.1 & 84.3 & 63.8 & 2.5 & 18.0 \\
\hline & 5 & 39.1 & 37.2 & 1.9 & 60.9 & 46.7 & 0.2 & 14.0 \\
\hline & 6 & $35.8 b$ & $31.3 b$ & 4.5 & $64.2 \mathrm{a}$ & $62.4 a$ & 0.9 & 0.9 \\
\hline \multirow[t]{6}{*}{$\mathrm{FM}-\mathrm{K}_{2} \mathrm{SO}_{4}$} & 1 & 89.7 & 89.7 & 0 & 10.3 & 10.3 & 0 & 0 \\
\hline & 2 & 9.7 & 9.7 & 0 & 90.3 & 72.9 & 0 & 17.4 \\
\hline & 3 & 21.6 & 21.6 & 0 & 78.4 & 78.4 & 0 & 0 \\
\hline & 4 & 13.8 & 13.8 & 0 & 86.2 & 83.5 & 0 & 2.7 \\
\hline & 5 & 61.6 & 61.6 & 0 & 38.4 & 38.4 & 0 & 0 \\
\hline & 6 & $56.4 a b$ & $56.4 a b$ & 0 & $43.6 a b$ & $36.0 a b$ & 0 & 7.6 \\
\hline \multirow{6}{*}{$\mathrm{FP}-\mathrm{H}_{2} \mathrm{O}$} & 1 & 63.5 & 61.3 & 2.2 & 36.5 & 34.3 & 2.2 & 0 \\
\hline & 2 & 14.6 & 14.6 & 0 & 85.4 & 85.4 & 0 & 0 \\
\hline & 3 & 30.8 & 26.9 & 3.9 & 69.2 & 65.2 & 0 & 4.0 \\
\hline & 4 & 24.4 & 18.0 & 6.4 & 75.6 & 74.1 & 0 & 1.5 \\
\hline & 5 & 33.9 & 28.3 & 5.6 & 66.1 & 65.0 & 1.1 & 0 \\
\hline & 6 & $11.4 b$ & $11.4 b$ & 0 & $88.6 a$ & $75.1 \mathrm{a}$ & 0 & 13.5 \\
\hline \multirow[t]{6}{*}{$\mathrm{FP}-\mathrm{K}_{2} \mathrm{SO}_{4}$} & 1 & 85.2 & 85.2 & 0 & 14.8 & 14.8 & 0 & 0 \\
\hline & 2 & 55.5 & 55.5 & 0 & 44.5 & 44.5 & 0 & 0 \\
\hline & 3 & 53.1 & 53.1 & 0 & 46.9 & 46.9 & 0 & 0 \\
\hline & 4 & 44.1 & 44.1 & 0 & 55.9 & 48.5 & 0 & 7.4 \\
\hline & 5 & 43.4 & 43.4 & 0 & 56.6 & 47.7 & 0 & 8.9 \\
\hline & 6 & $63.1 \mathrm{a}$ & $63.1 a$ & 0 & $36.9 b$ & $36.9 b$ & 0 & 0 \\
\hline
\end{tabular}

The different superscript letters indicate significant differences at the $P<0.05$ level among four extraction methods. Chemical compounds such as lipids and aromatics were classified as Ho-compounds, whereas organic acids, phenols, and $\mathrm{N}$-compounds were grouped as $\mathrm{Hi}-\mathrm{compounds}$. Abbreviations: $\mathrm{FM}-\mathrm{H}_{2} \mathrm{O}$; Filter membrane- $\mathrm{H}_{2} \mathrm{O}$. FM-K $\mathrm{SOO}_{4}$; Filter membrane- $\mathrm{K}_{2} \mathrm{SO}_{4}$. $\mathrm{FP}-\mathrm{H}_{2} \mathrm{O}$; Filter paper- $\mathrm{H}_{2} \mathrm{O}$. $\mathrm{FP}-\mathrm{K}_{2} \mathrm{SO}_{4}$; Filter paper-K $\mathrm{SO}_{4}$. Hi-compound; hydrophilic compound.

Ho-compound; hydrophobic compound

\section{Distribution of DOM components across the molecular weight range}

The distributions of DOM components extracted by $\mathrm{H}_{2} \mathrm{O}$ and $\mathrm{K}_{2} \mathrm{SO}_{4}$ using the same filter material were different (Fig. 1, Fig. 2). In the same FM or FP filtrate, DOM components less than $100 \mathrm{Da}$ in size were only found in the $\mathrm{H}_{2} \mathrm{O}$ extract (Fig. 1a, c), which accounted for $0.24 \%$ or $0.68 \%$ of the Hi-compounds (Fig. $2-a$, c), and $0.21 \%$ or $1.28 \%$ of the Ho-compounds in the DOM composition (Fig. 2-e, g), respectively; DOM components larger than $400 \mathrm{Da}$ in size were only found in the $\mathrm{K}_{2} \mathrm{SO}_{4}$ extract (Fig. 1-b, d), which was composed of $10.5 \%$ or 16.4\% Ho-compounds in FM or FP filtrate (Fig. 2-f, h), respectively. This indicates that the composition of the DOM extracted by $\mathrm{K}_{2} \mathrm{SO}_{4}$ was more complex than that extracted by $\mathrm{H}_{2} \mathrm{O}$.

\section{DISCUSSION}

Generally, $\mathrm{H}_{2} \mathrm{O}$ extracts are composed of dissolved and weakly adsorbed compounds (Joo et al., 2008). The results from this study show that the $\mathrm{K}_{2} \mathrm{SO}_{4}$ extracts contain more DOC than the $\mathrm{H}_{2} \mathrm{O}$ extracts. $\mathrm{As}_{2} \mathrm{SO}_{4}$ is a salt, its ions can assist in the dissolution of chemical compounds initially adsorbed onto soil particles through ion-exchange interactions (Jones and Willett, 2006). Thereby, in addition to soluble and weakly adsorbed compounds, the $\mathrm{K}_{2} \mathrm{SO}_{4}$ extracts also contain adsorptive compounds. Compared with $\mathrm{H}_{2} \mathrm{O}$, the $\mathrm{K}_{2} \mathrm{SO}_{4}$ extracts contained larger hydrophobic fractions (Table 3, Fig. 2-a, b, c, d) that are readily adsorbed on soil particles, which reveals the higher DOC-extraction capacity of $\mathrm{K}_{2} \mathrm{SO}_{4}$ over $\mathrm{H}_{2} \mathrm{O}$. The hydrophobic fractions in the $\mathrm{K}_{2} \mathrm{SO}_{4}$ extracts are composed of aliphatic constituents 


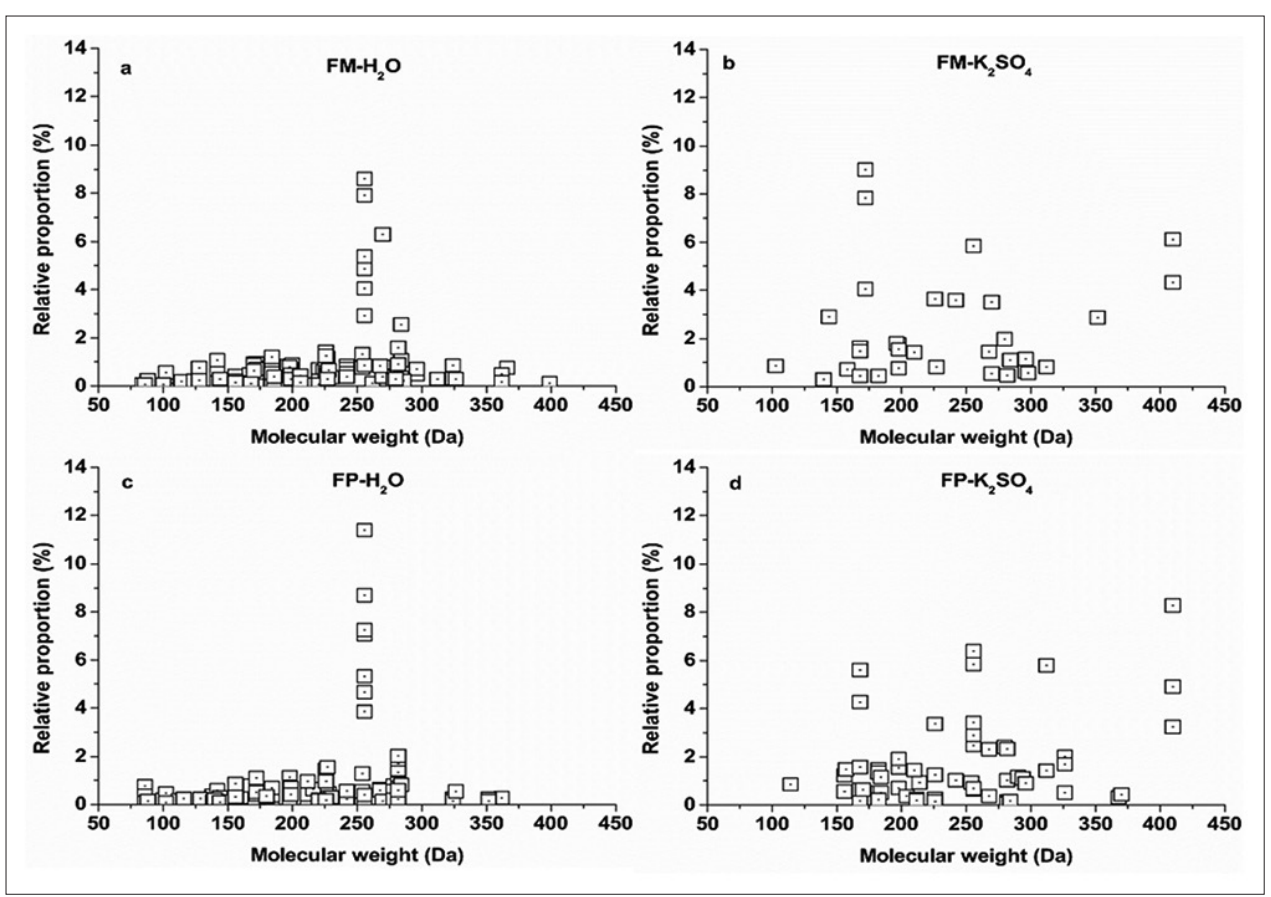

Fig 1. Relative proportion of DOC compounds of different molecular weight ranges. The data portray the mixed results of all experimental soils.

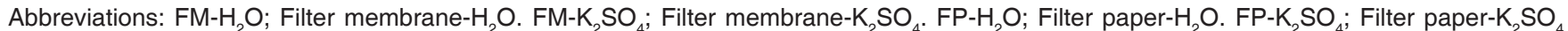
According to the relative proportion of chemical composition from six DOM samples and their DOC contents, we mixed the chemical composition of DOM together to evaluate molecular weight distributions of DOM components. The relative proportion of each component was calculated as $\mathrm{p} \times \mathrm{c} /(\mathrm{c} 1+\mathrm{c} 2+\mathrm{c} 3+\mathrm{c} 4+\mathrm{c} 5+\mathrm{c} 6) \times 100 \%$. $\mathrm{p}$ : the relative proportion of each component. c: the soil DOC content. $\mathrm{c} 1-\mathrm{c} 6$ : The DOC content from six soil DOM samples, respectively.

rather than aromatic compounds (Table 3), which may be related to the rich aliphatic content of the organic materials in farmland soils, such as straw and cellulose (Putun et al., 2004; Wu, 2013).

In addition, filter materials also affect the DOC content. FP filtrates were shown to contain higher DOC contents than FM filtrates, due to the larger pore size (2.5 vs. $0.45 \mathrm{~mm}$, respectively). Of the particulate organic carbon, very fine particles of about 0.45 to $6 \mathrm{~mm}$ in size constitute the major fraction. Furthermore, most bacteria and phytoplankton are larger than $0.45 \mathrm{~mm}$. Colloidal matter consisting of fine particles in the $0.001-1.0 \mathrm{~mm}$ range is regarded as 'subparticulate' (between particulate and dissolved organic matter). Therefore, very fine particulate organic matter, some bacteria and phytoplankton (0.45-2.5 mm), and colloidal matter $(0.45-1.0 \mathrm{~mm})$ largely account for the higher levels of organic carbon in the FP filtrates $(2.5 \mathrm{~mm})$.

Bioavailability is a vital index with which to evaluate DOC characteristics, and is determined by chemical composition (Marschner and Kalbitz, 2003; Kalbitz et al., 2000). The results show that more hydrophobic compounds are recovered by $\mathrm{K}_{2} \mathrm{SO}_{4}$ extraction, and components with diameters of $0.45-2.5 \mathrm{~mm}$ are contained in the FP filtrates (Table 3). Particulate organic matter is relatively high in inorganic content and is heterogeneous in composition (e.g., containing lignins, lipids, and humic substances) (Sundh, 1992). Hydrophilic compounds are more readily used by microorganisms, whereas hydrophobic compounds are refractory (Lichter et al., 2005; Kalbitz and Kaiser, 2008). Soil colloidal matter is rich in humic acid, which is composed of aromatic compounds, saccharides, and fatty acids (Junet et al., 2013; Chen and Sparks, 2015). Finally, cell walls are the primary organelles of bacteria, and contain peptidoglycans, teichoic acid, lipopolysaccharides, and so on (Cummins and Harris, 1956). These high-molecularweight chemical compounds are complex and refractory to microbial degradation (Repeta et al., 2002). This clearly demonstrates that the $\mathrm{K}_{2} \mathrm{SO}_{4}$-FP method increases the complexity of the extracted DOM as compared with the $\mathrm{H}_{2} \mathrm{O}-\mathrm{FM}$ method. Consequently, research based on DOM materials extracted by different methods may lead to different results, because various DOM components play different roles in ecological processes. For example, during the microbial degradation of DOM, components rich in $\mathrm{N}$ and $\mathrm{P}$ (i.e., amino acids and nucleotides) are transformed into inorganic nutrients (i.e., ammonium, nitrate, phosphate) (Moschonas et al., 2017; Brailsford et al., 2017). Low-molecular weight organic acids can improve the transport of metal ions in soil through the formation of metal-organic acid complexes (Wu et al., 2010). Complex compounds generally contribute to SOM sequestration, 

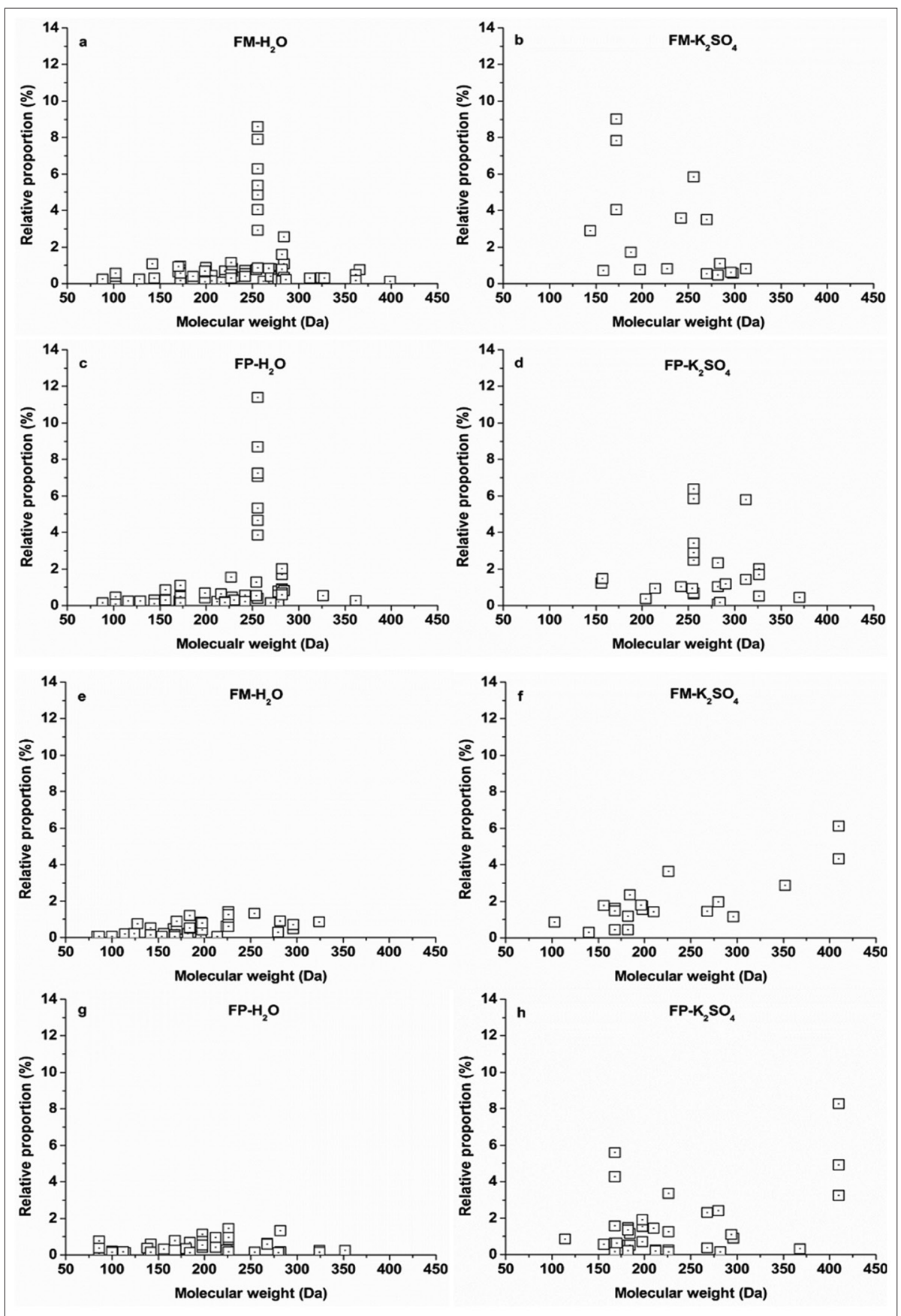

Fig 2. Relative proportion of hydrophilic (Fig. 2-a, b, c, d) and hydrophobic (Fig. 2-e, f, g, h) fractions at different molecular weights for different

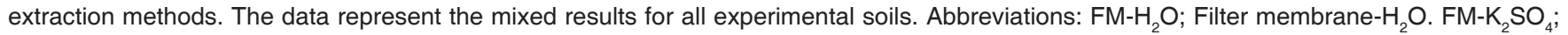
Filter membrane- $\mathrm{K}_{2} \mathrm{SO}_{4}$. $\mathrm{FP}-\mathrm{H}_{2} \mathrm{O}$; Filter paper- $\mathrm{H}_{2} \mathrm{O}$. $\mathrm{FP}-\mathrm{K}_{2} \mathrm{SO}_{4}$; Filter paper- $\mathrm{K}_{2} \mathrm{SO}_{4}$.

as they are less used by microorganisms (Nebbioso and Piccolo, 2013; Cotrufo et al., 2013).

Pyrolysis-GC/MS is a powerful tool for the determination of organic matter composition, which can be used for the detailed separation, identification, and relative quantification of individual DOM components. Through the controlled thermal degradation of DOM during py-GCMS analysis, the original structures of the DOM components can be determined from the pyrolysis products in the pyrogram
(Schulten and Gleixner, 1999; Leenheer and Croue, 2003; Greenwood et al., 2012). However, the molecular-weight distributions of DOM components obtained through different extraction methods needs to be investigated.

\section{CONCLUSION}

Due to their different pore sizes, filter materials significantly influenced DOC content $(p<0.05)$, but not DOM 
composition $(p>0.05)$. Due to differences in extraction abilities, extractants can significantly influence the quantity and quality of DOM. This study demonstrated that, compared with the FM- $\mathrm{H}_{2} \mathrm{O}$ method, DOM extracted by the $\mathrm{FP}-\mathrm{K}_{2} \mathrm{SO}_{4}$ method was characteristically higher in content and complexity. In view of this, the effect of the extraction method on DOM properties should be noted when studying composition and ecological processes of DOM.

\section{ACKNOWLEDGEMENTS}

This work was jointly supported by Natural Science Foundation of China (41471199, 41301273).

\section{Author's contributions}

X. D. Zheng and C. M. Liang: statistical analysis, wrote the article. X. B. Chen and Y. J. Hu: contributed to writing of discussions. J. S. Wu and Y. R. Su: study design, supervision of study.

\section{REFERENCES}

Boddy, E., P. W. Hill, J. Farrar and D. L. Jones. 2007. Fast turnover of low molecular weight components of the dissolved organic carbon pool of temperate grassland field soils. Soil Biol. Biochem. 39: 827-835.

Brailsford, F. L., H. C. Glanville, M. R. Marshall, P. N. Golyshin, P. J. Johnes, C. A. Yates, A. T. Owen and D. L. Jones. 2017. Microbial use of low molecular weight DOM in filtered and unfiltered freshwater: Role of ultra-small microorganisms and implications for water quality monitoring. Sci. Total Environ. 598: 377-384.

Chantigny, M. H., T. H. Kirk, D. Curtin and M. Beare. 2014. Temperature and duration of extraction affect the biochemical composition of soil water-extractable organic matter. Soil Biol. Biochem. 75: 161-166.

Chen, C. M. and D. L. Sparks. 2015. Multi-elemental scanning transmission X-ray microscopy-near edge X-ray absorption fine structure spectroscopy assessment of organo-mineral associations in soils from reduced environments. Environ. Chem. 1: 64-73.

Cotrufo, M. F., M. D. Wallenstein, C. M. Boot, K. Denef and E. Paul. 2013. The microbial efficiency-matrix stabilization (MEMS) framework integrates plant litter decomposition with soil organic matter stabilization: Do labile plant inputs from stable soil organic matter? Glob. Change Biol. 19: 988-995.

Cummins, C. S. and H. Harris. 1956. The chemical composition of the cell wall in some gram-positive bacteria and its possible value as a taxonomic character. Microbiology. 14: 583-600.

Feng, W. T., A. F. Plante, A. K. Aufdenkampe and J. Six. 2014. Soil organic matter stability in organo-mineral complexes as a function of increasing C loading. Soil Biol. Biochem. 69: 398-405.

Greenwood, P. F., L. J. Berwick and J. P. Croue. 2012. Molecular characterization of the dissolved organic matter of wastewater effluents by MSSV pyrolysis GC-MS and search for source markers. Chemosphere. 87: 504-512.

Han, C. W., Z. P. Li and L. Liu. 2007. Influence on carbon and nitrogen mineralization after dissolved organic matter removal in subtropical Chinese paddy soils. Sci. Agric. Sin. 40: 107-113.

Jardine, P. M., J. F. McCarthy and N. L. Weber. 1989. Mechanisms of dissolved organic carbon adsorption on soil. Soil Sci. Soc. Am. J. 53: 1378-1385.

Jones, D. L. and V. B. Willett. 2006. Experimental evaluation of methods to quantify dissolved organic nitrogen (DON) and dissolved organic carbon (DOC) in soil. Soil Biol. Biochem. 38: 991-999.

Joo, J. C., C. D. Shackelford and K. F. Reardon. 2008. Sorption of nonpolar neutral organic compounds to humic acid-coated sands: Contributions of organic and mineral components. Chemosphere. 70: 1290-1297.

Junet, A. D., I. B. Doelsch, D. Borschneck, A. Masion, S. Legros, C. Marol, J. Balesdent, J. Templier and S. Derenne. 2013. Characterisation of organic matter from organo-mineral complexes in an Andosol from Reunion Island. J. Anal. Appl. Pyrol. 99: 92-100.

Kalbitz, K. and K. Kaiser. 2008. Contribution of dissolved organic matter to carbon storage in forest mineral soils. J. Plant Nutr. Soil Sci. 1: 52-56.

Kalbitz, K., S. Solinger, J. H. Park, B. Michalzik and E. Matzner. 2000. Controls on the dynamics of dissolved organic matter in soils: A review. Soil Sci. 165: 277-304.

Kalmykova, Y., N. Moona, A. M. Stromvall and K. Bjorklund. 2014. Sorption and degradation of petroleum hydrocarbons, polycyclic aromatic hydrocarbons, alkylphenols, bisphenol A and phthalates in landfill leachate using sand, activated carbon and peat filters. Water Res. 56: 246-257.

Karickhoff, S. W., D. S. Brown and T. A. Scott. 1979. Sorption of hydrophobic pollutants on natural sediments. Water Res. 13: $241-248$.

Leenheer, J. A. and J. P. Croue. 2003. Peer reviewed: Characterizing aquatic dissolved organic matter. Environ. Sci. Technol. 37: 18-26.

Li, L., H. A. Xiao, Y. R. Su, D. Y. Huang and J. S. Wu. 2008. Effects of land use on the content of soil dissolved organic carbon in the typical landscape units in subtropical red earth region. Sci. Agric. Sin. 41: 122-128.

Lichter, J., S. H. Barron, C. E. Bevacqua, A. C. Finzi, K. F. Irving, E. A. Stemmler and W. H. Schlesinger. 2005. Soil carbon sequestration and turnover in a pine forest after six years of atmospheric $\mathrm{CO}_{2}$ enrichment. Ecology. 86: 1835-1847.

Lu, X. Q., N. Maie, J. V. Hanna, D. L. Childers and R. Jaffe. 2005. Molecular characterization of dissolved organic matter in freshwater wetlands of the Florida Everglades. Water Res. 37: 2599-2606.

Lu, Y. H., A. Watanabe and M. Kimura. 2004. Contribution of plant photosynthates to dissolved organic carbon in a flooded rice soil. Biogeochemistry. 71: 1-15.

Marschner, B and K. Kalbitz. 2003. Controls of bioavailability and biodegradability of dissolved organic matter in soils. Geoderma. 113: 211-235.

McDowell, W. H., A. Zsolnay, J. A. Peterson, E. G. Gregorich, D. L. Jones, D. Jodemann, K. Kalbitz, B. Marschner and D. Schwesig. 2006. A comparison of methods to determine the biodegradable dissolved organic carbon from different terrestrial sources. Soil Biol. Biochem. 38: 1933-1942.

Moschonas, G. M., R. J. Gowen, R. F. Paterson, E. Mitchell, B. M. Stewart, S. McNeill, P. M. Glibert and K. Davidson. 2017. Nitrogen dynamics and phytoplankton community structure: The role of organic nutrients. Biogeochemistry. 134: 125-145. 
Nebbioso, A. and A. Piccolo. 2013. Molecular characterization of dissolved organic matter (DOM): A critical review. Anal. Bioanal. Chem. 405: 109-124.

Ogura, N. 1974. Molecular weight fractionation of dissolved organic matter in coastal seawater by ultrafiltration. Mar. Biol. 24: 305-312.

Peltzer, E. T., B. Fry, P. H. Doering, J. H. Mckenna, B. Norrman and U. L. Zweifel. 1996. A comparison of methods for the measurement of dissolved organic carbon in natural waters. Mar. Chem. 54: 85-96.

Plant, E. L., R. J. Smernik, J. V. Leeuwen, P. Greenwood and L. M. Macdonald. 2015. Changes in the nature of dissolved organics during pulp and paper mill wastewater treatment: A multivariate statistical study combining data from three analytical techniques. Environ. Sci. Pollut. Res. 21: 4265-4275.

Pullicino, D. S. and G. Gigliotti. 2007. Oxidative biodegradation of dissolved organic matter during composting. Chemosphere. 68: 1030-1040.

Putun, A. E., E. Apaydin and E. Putun. 2004. Rice straw as a bio-oil source via pyrolysis and steam pyrolysis. Energy. 29: $2171-2180$.

Repeta, D. J., T. M. Quan, L. I. Aluwihare and A. Accardi. 2002. Chemical characterization of high molecular weight dissolved organic matter in fresh and marine water. Geochim. Cosmochim. Ac. 6: 955-962.

Rousk, J. and D. L. Jones. 2010. Loss of low molecular weight dissolved organic carbon (DOC) and nitrogen (DON) in $\mathrm{H}_{2} \mathrm{O}$ and $0.5 \mathrm{M} \mathrm{K}_{2} \mathrm{SO}_{4}$ soil extracts. Soil Biol. Biochem. 42: 2331-2335.

Saiz-Jimenez, C. 1994. Pyrolysis/methylation of soil fulvic acids: Benzenecarboxylic acids revisited. Environ. Sci. Technol. 28: 197-200.

Schulten, H. R. and G. Gleixner. 1999. Analytical pyrolysis of dissolved organic matter in aquatic systems: Structure and origin. Water
Res. 33: 2489-2498.

Sihombing, R., P. F. Greenwood, M. A. Wilson and J. V. Hanna. 1996. Composition of size exclusion fractions of swamp water humic and fulvic acids as measured by solid state NMR and pyrolysisgas chromatography-mass spectrometry. Org. Geochem. 24: 859-873.

Straathof, A. L., R. Chincarini, R. N. Comans and E. Hoffland. 2014. Dynamics of soil dissolved organic carbon pools reveal both hydrophobic and hydrophilic compounds sustain microbial respiration. Soil Biol. Biochem. 79: 109-116.

Sundh, I. 1992. Biochemical composition of dissolved organic carbon derived from phytoplankton and used by heterotrophic bacteria. Appl. Environ. Microb. 58: 2938-2947.

Troyer, I. D., F. Amery, C. V. Moorleghem, E. Smolders and R. Merckx. 2011. Tracing the source and fate of dissolved organic matter in soil after incorporation of $a{ }^{13} \mathrm{C}$ labelled residue. Soil Biol. Biochem. 43: 513-519.

Van Hees, P. A. W., D. L. Jones, R. Finlay, D. L. Godbold and U. S. Lundstrom. 2005. The carbon we do not see-the impact of low molecular weight compounds on carbon dynamics and respiration in forest soils: A review. Soil Biol. Biochem. 37: 1-13.

Wu, C. S. 2013. Aliphatic polyester-based green renewable ecocomposites from agricultural residues: Characterization and assessment of mechanical properties. J. Polym. Environ. 21: 421-430.

Wu, G., H. B. Kang, X. Y. Zhang, H. B. Shao, L. Y. Chu and C. J. Ruan. 2010. A critical review on the bio-removal of hazardous heavy metals from contaminated soils: Issues, progress, ecoenvironmental concerns and opportunities. J. Hazard. Mater. 174: $1-8$.

Zhou, P., G. X. Pan, R. Spaccini and A. Piccolo. 2010. Molecular changes in particulate organic matter (POM) in a typical Chinese paddy soil under different long-term fertilizer treatments. Eur. J. Soil Sci. 61: 231-242. 